\title{
Estimated Economic Impacts of the 2019 Midwest Floods
}

\author{
Burton C. English ${ }^{1}$. S. Aaron Smith ${ }^{2} \cdot$ R. Jamey Menard ${ }^{2} \cdot$ David W. Hughes $^{2}$. \\ Michael Gunderson ${ }^{3}$
}

Received: 5 February 2021 / Accepted: 15 August 2021 / Published online: 10 September 2021 (C) The Author(s) 2021

\begin{abstract}
In the spring of 2019, U.S. agriculture experienced a record high number of prevented planted acres primarily due to historic rainfall across large portions of the Corn Belt and Mid-South. Producers of corn, upland cotton, soybean, and wheat were impacted with a substantial loss of revenue due to no crops being produced and marketed. With about 11.4 million acres of corn not planted, foregone gross revenue from crop sales likely exceeded $\$ 6$ billion alone. Instead of focusing on the loss of producers' incomes as a result of prevented planted acres, our analysis focuses on the economic impacts, due to lost sales, for firms that provide inputs to farmers. Acres prevented from planting resulted in producers not incurring typical expenditures for planting and post planting inputs such as seed, crop nutrients, and crop protection (herbicides, insecticides, fungicides, etc.). Agricultural input manufacturers, wholesalers, and retailers do not have similar opportunities to insure against foregone sales and have received no disaster assistance payments. Normally, the large geographic footprint of many of these firms mitigates the impact of localized weather effects. However, given the widespread nature of the wet spring, these firms were negatively affected across Corn Belt and Mid-South representing a substantial production area. Regional economic impact of declines in sales by agricultural input providers due to wet weather-based prevented plantings on 13.1 million acres. Direct sale losses of $\$ 2.9$ billion led to $\$ 4.5$ billion losses in total sales that were concentrated in parts of Minnesota, South Dakota, and Illinois.
\end{abstract}

Keywords 2019 Midwestern floods · Input manufacturers · Prevented plantings · Economic impacts $\cdot$ Input-output

S. Aaron Smith

ssmit263@tennessee.edu

R. Jamey Menard

rmenard@tennessee.edu

1 University of Tennessee Institute of Agriculture (UTIA) Institute Professor, Department of Agricultural and Resource Economics, University of Tennessee, Knoxville, TN, USA

2 Department of Agricultural and Resource Economics, University of Tennessee, Knoxville, TN, USA

3 MetLife Investment Management, Whippany, NJ, USA 


\section{Introduction}

In the spring of 2019, U.S. agriculture experienced a record high number of prevented planted acres primarily due to historic rainfall across large portions of the Corn Belt and Mid-South (Newton 2019a). Producers of corn, upland cotton, soybean, and wheat were impacted with a substantial loss of revenue due to no crops being produced and marketed. With about 11.4 million acres of corn not planted, foregone gross revenue from crop sales likely exceeded $\$ 6$ billion. For soybeans, wheat, and upland cotton, those numbers are estimated at 4.5 million acres and \$2 billion, 2.2 million acres and \$930 million, and 0.49 million acres and $\$ 325$ million, respectively.

To a large extent, prevented planting crop insurance and federal disaster assistance payments will reduce the adverse financial impact of a particularly wet spring on producers' incomes. Full prevented planting crop insurance indemnities paid to producers are equal to the crop insurance guarantee (revenue or yield) multiplied by a commodity specific prevented planting factor for 2019 (corn $-55 \%$, upland cotton - 50\%, soybeans $-60 \%$, and wheat $-60 \%)$. For example, a producer who purchased corn revenue insurance could receive a \$308/acre prevented planting crop insurance indemnity. ${ }^{1}$ Additionally, the federal government provided $\$ 3$ billion in farm disaster assistance under the Wildfire and Hurricane Indemnity Program Plus (WHIP+) (Newton 2019b). Thus, while it might not have been a particularly satisfying crop year, the adverse impact on producers' incomes will be partially mitigated through federal government programs and payments. Other agricultural economists have already analyzed the farm level financial impacts (see for example: Newton 2019a, b; Schnitkey et al. 2019; Purdue University Center for Commercial Agriculture 2019).

Instead of focusing on the loss of producers' incomes as a result of prevented planted acres, our analysis focuses on the economic impacts, due to lost sales, for firms that provide inputs to farmers. Acres prevented from planting resulted in producers not incurring typical expenditures for planting and post planting inputs such as seed, crop nutrients, and crop protection (herbicides, insecticides, fungicides, etc.). Agricultural input manufacturers, wholesalers, and retailers do not have similar opportunities to insure against foregone sales and have received no disaster assistance payments. Normally, the large geographic footprint of many of these firms mitigates the impact of localized weather effects. However, given the widespread nature of the wet spring, these firms were negatively affected across the Corn Belt and Mid-South, representing a substantial production area.

Our analysis estimates the direct, indirect, and induced economic impact (multiplier impact) as a result of lost sales from firms that provide inputs to corn, upland cotton, soybeans, and wheat farmers including support activities (e.g. custom planting and application), petroleum refineries and manufacturing, fertilizer manufacturing and mixing, pesticide and other agricultural chemical manufacturing, transportation, and agricultural wholesale trade and retail. For our study region, the result of prevented planted acres in the 2019 crop year was a decrease in input purchases and, therefore, a decrease in transactions by producers of an estimated $\$ 2.9$ billion to agribusiness firms. The research objective was to understand the scope and distribution of those foregone crop production expenditures among firms operating in the value chain before

\footnotetext{
1 Assumes 175 bu./acre APH x $\$ 4.00 /$ bu. projected crop insurance price $\times 80 \%$ buy-up $=\$ 560$ revenue guarantee; $\$ 560 \times 55 \%=\$ 308 /$ acre.
} 
the farm gate. The $\$ 2.9$ billion impact has substantial consequences for the firms operating in these sectors. With much of the infrastructure fixed and limited flexibility in reducing the labor force, profitability of agribusiness firms likely suffered as a result. The impact was largely shouldered by the agricultural retail sector. As farmers chose not to plant a crop, this eliminated the need for crop nutrients and protection chemicals. Agricultural retailers are largely reliant on a fixed infrastructure to manage inventories of these inputs in a relatively limited planting window. The reduction in inputs is exacerbated by a reduction in the need for custom application of these nutrients and protection chemicals. This reduction was passed up the value chain to manufacturers as well. A smaller, but significant portion of the reduction (more than $\$ 50$ million) also impacted transportation.

\section{Previous Studies}

Previous studies indicates very little evaluation of the economy-wide impacts of flooded agricultural land in the U.S. Zacharia (1993) evaluated the impact of the 1993 Midwestern flood on regional agriculture, but did not examine impacts on other parts of the economy. Hewings and Mahidhara (1993) did evaluate the impact of this flood on the Iowa economy through reduction in agricultural production based on a state input-output model. They indicated a temporary decline in state economic activity of $1.5 \%$ due to the flood. In their evaluation of the Birds Point-New Madrid Floodway Levee Breach, Brown et al. (2011) indicated direct crop loss of $\$ 85.2$ million resulting in at most a $\$ 156.7$ million impact on the Missouri state economy based on an IMPLAN model. However, the latter value did not reflect the impact of spending on crop production before the flood.

Several of these studies have been conducted regarding the regional impact of floods in other countries. For example, Carrera et al. (2015) examined the economic impact of the 2000 Po River flood on affected regions in northern Italy based on a combination of a regional Computable General Equilibrium (CGE) model and spatial analysis of damaged lands. The results indicated that indirect impacts are an important component of the social loss due to the flood. Hallegatte (2008) employed an input-output model to assess the damage of Katrina on the Louisiana economy through an adaptive modeling approach. Although agriculture is included as an impacted sector, the impact was based on broad assumptions regarding the duration of the impact across the entire economy. Likewise, Wang et al. (2017) included agriculture in their assessment of typhoon damage based on input-output analysis for Taiwan. Borgomeo et al. (2018) examined the economy-wide impacts of decreases and increases in rainfall on agricultural production for the Wash Basin in Ethiopia based on a regional CGE model.

A few studies have been conducted regarding the economy-wide impact of drought on agriculture and resulting impacts on state economies. For example, Diersen and Taylor used an input-output model of the South Dakota economy to estimate the impact of the 2002 drought. They also included resulting price increases in 2003 in their analysis that reduced the ultimate impact by around two-thirds. Several other studies conducted for Illinois (Kunkel et al. 2006) and Oklahoma (Arndt 2002) have examined the impact of drought directly on agriculture with some analysis of the impact on selected other industries such as the shipping or retail sectors. 


\section{Modeling Activities Used in this Analysis}

Two models were used to estimate the estimated impacts of the 2019 flood - IMPLAN and POLYSYS. POLYSYS supplied the necessary data for determining foregone expenditures and IMPLAN used this information to estimate the negative economic impacts.

\section{POLYSYS Model}

The University of Tennessee's Policy Analysis System Model (POLYSYS) is a spatial dynamic partial equilibrium displacement model of US agriculture and forestry sectors (De La Torre et al. 1998, De La Torre and Ray 2000). The structure of POLYSYS can be viewed as a system of interdependent modules simulating (a) county-level crop production; (b) national crop demands and prices; (c) national livestock supplies and demands, along with providing agricultural income, planted and harvested area, production inputs, yields, exports, costs of production, demand by use, commodity price, and government program outlays.

POLYSYS anchors its analyses to USDA's published baseline projections for the agriculture sector, which can be forecasted to 2050. Changes in agricultural land use, based on cropland allocation decisions made by individual farmers, are driven by the expected productivity of land, crop production costs, the expected economic returns to crops, and domestic and world market demand. County-level cropland area (2018-2019) and tillage mixes are used as an initial point of departure for projections. Changes in land use and correspondingly, input use, can be backward linked to input markets, as well as forward linked to the food and fiber processing sector and agricultural value-added industries. The model's database contains cost information on program crops such as corn, grain sorghum, oats, barley, wheat, soybeans, cotton, and rice. Hay costs are also included in the database. These costs originate from $13^{2}$ sourced regional budgets for each crop and tillage combination to estimate budgets in all 305 regions using 'inverse distance weighting' interpolation for costs and input quantities (Hellwinckel 2019). The 13 sourced budgets representing 2018 production practices roughly correspond to the Farm Resource Regions defined by the USDA as unique cropping regions.

\section{IMPLAN Input-Output Model}

The primary tool used in estimating economic impacts was a set of regional input-output models, which depicts transactions between supplier and consumers, typically in a regional economy. These models typically reflect an economic region and are used to analyze the effects of changes in that region's economy (Miller and Blair 2009).

Input-output (I-O) models, such as IMPLAN, examine the market flows of products between industries, sales by industries to households and other final users, and industry use of factors of production (labor and capital). These models can be very detailed containing several hundred industries. (The IMPLAN model used in this study contained over 500 industries based on the North American Classification

${ }^{2}$ USDA has defined 13 different farm production regions (USDA/ERS 2000). 
System (NAICS) (US Census Bureau 2012)). The multipliers generated in I-O models are based on the key assumption of fixed-proportion production functions, where input use moves in lockstep fashion with production. For directly affected industries we relax this assumption, however, to appropriately model the impact of flooding for agriculture in the affected areas. Specifically, because of flooding, the lockstep assumption was relaxed as fixed cost spending proceeded while variable cost spending did not.

IMPLAN (2000) is an I-O model building system providing data for every U.S. county. Regional I-O models are based on the production and consumption relationships found in the national I-O model. For example, if $10 \%$ of all spending by the grain farming sector goes to the national fertilizer sectors, then that assumption will also hold for any regional model. However, regional size indicators (such as regional employment in fertilizer production) will be imposed in determining relationships and regional buying and selling patterns (for example, if the region has no fertilizer producers, then all such purchases will be made outside the local economy), which determine multipliers and impacts.

Economic impacts are based on economic multipliers that reflect the strength of local buying and selling relationships by accounting for the "round-robins" of re-spending of expenditures interjected into a regional economy. Accordingly, as the level of purchases with a region increases (with reduced spending outside of the region), the size of the local multiplier increases. Thus, these models can show how an industry or event affects an entire regional economy.

Multiplier analysis generally focuses on the impacts of exogenous changes on: a) changes in output of sector(s) in the economy, b) changes in contribution to factors of production (Gross Regional Product) including changes in income earned by households, and c) changes in employment resulting from in this case reduced spending by producers. The concept of multipliers rests on the difference between the initial impact of an exogenous change and the total impacts of a change. The direct impact in this case is reduced spending by producers on selected inputs as a result of flooding. Total impacts are the sum of direct impacts, plus the estimated economic impacts from purchase reductions in inputs such as electricity, feed, building/equipment repairs, insurance providing goods and services (indirect impacts), and decreased expenditures resulting from new household income (induced impacts) as a result of the reduction in production expenditures by producers on selected inputs. For the IMPLAN economic activity calculated, projections of changes for the 54 Bureau of Economic Analysis (BEA) economic based regional models used an analysis-by-parts (ABP) methodology (Clouse 2021; Markel et al. 2018). ${ }^{3}$ The goods and service demanded from multiple industries were used to produce the impact. This analysis also uses the local purchase percentage (LPP) option available in IMPLAN modeling. Consequently, this affects the impact value applied to the multipliers. Instead of a $100 \%$ direct expenditure value applied to the multiplier, the model is set to the value which reflects purchases within the respective BEA.

\footnotetext{
${ }^{3}$ Analysis-by-parts essentially splits the economic impacts. Instead of a single industry shock, the technique breaks down the impact into separate components, which is the recommended methodology to use if the multiplier matrix doesn't require a change and the impact is a subset of a current IMPLAN industry.
} 


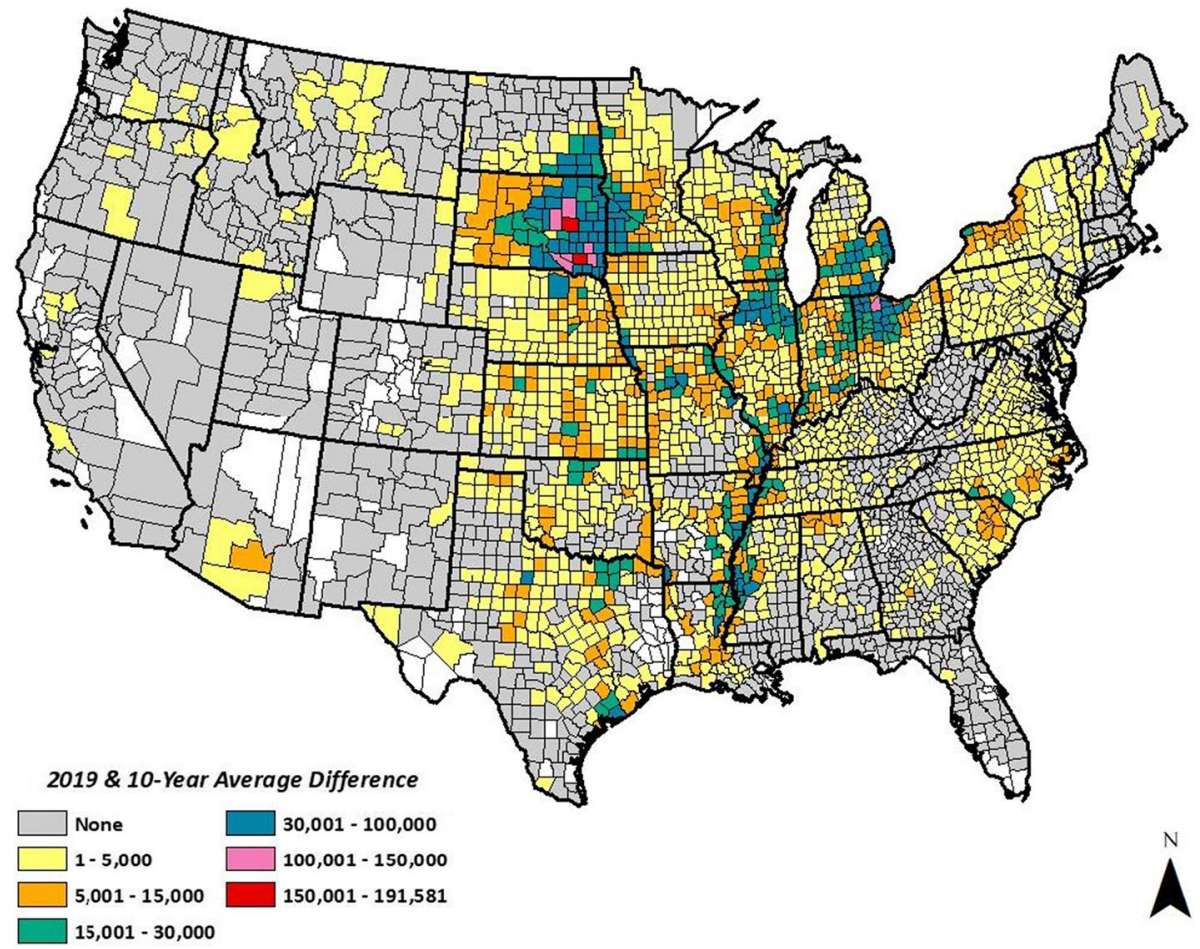

Fig. 12019 FSA county-level prevented planting acres less 10-year average prevented planting acres. Source: (adapted from USDA-FSA 2019a) 1

\section{Estimating Economic Impacts}

First, prevented planting acre data corn, upland cotton, soybean, and wheat was obtained from U.S. Department of Agriculture's Farm Service Agency (USDAFSAa). Producers are required annually to self-report crop acreage data to FSA in order to maintain eligibility for program like Agriculture Risk Coverage (ARC), Price Loss Coverage (PLC), marketing assistance loans, loan deficiency payments, or disaster assistance payment programs (USDA-FSA 2019b). Reporting dates vary but, in general, producers must report spring planted crops by July 15 . Because of excess moisture during the 2019 spring planting period, the acreage reporting deadline was extended to July 22 for Arkansas, Illinois, Indiana, Iowa, Kentucky, Michigan, Missouri, Minnesota, North Dakota, Ohio, Tennessee, and Wisconsin producers (USDA-FSA 2019b). Acreage reported beyond the deadline was considered late and can only be accepted under extenuating circumstances, which are not unreasonably withheld. For each county, cropland data are reported for three primary categories -- planted $(217,644,905)$, failed $(1,694,797)$, and prevented planted $(18,260,845) .{ }^{4}$ The August 1 st crop acreage

\footnotetext{
4 Totals for corn, upland cotton, soybean, and wheat acres reported August 1, 2019 and published August 12,2019 are shown in parenthesis.
} 


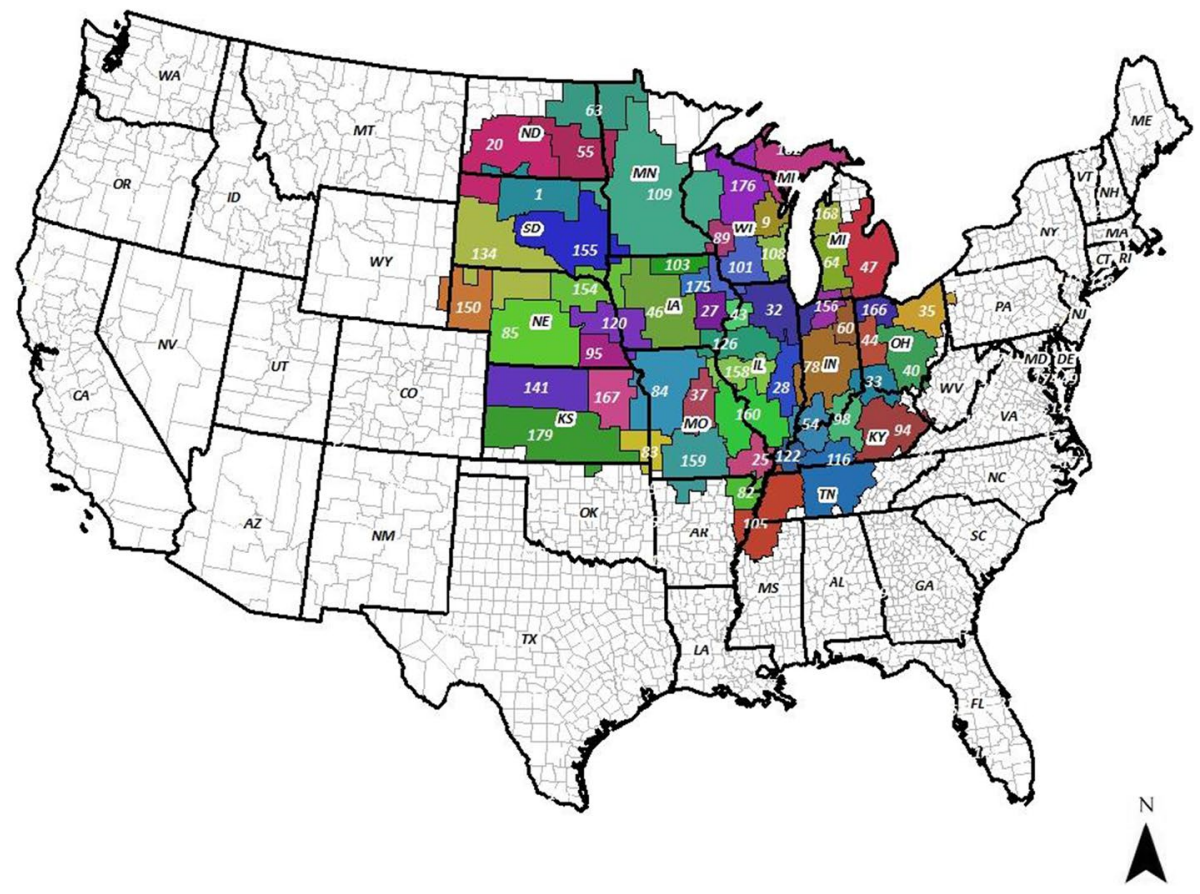

Fig. 2 Midwest flood region by BEA economic areas occurring in the study region. Source: (adapted from Johnson and Kort 2004)

data will be revised each month until January when the FSA crop acreage data is finalized for the year.

For the analysis, county level prevented planting acres for corn, upland cotton, soybean, and wheat were collected for the previous ten crop years (2009-2018) to establish a baseline. On a county-by-county basis, 2019 corn, upland cotton, soybean, and wheat prevented planting acres were subtracted by the ten-year county average prevented planting acres to determine deviation from the baseline (Fig. 1).

The county-level data were spatially aggregated into U.S. Department of Commerce's, Bureau of Economic Analysis Economic Areas (BEA) (Fig. 2) (Appendix Table 2). If a BEA recorded a difference of 5000 prevented planting acres or more when compared to the 10-year average, it was included in the study. In order to establish the direct costs/ shock for IMPLAN modeling at the BEA level, the acres in each of the 54 BEAs in the study were broken out by crop (corn, upland cotton, soybean, and wheat) and multiplied by per acre budgeted variable costs ${ }^{5}$ from the POLYSYS database (Slinsky and Tiller 1999; Nelson et al. 2009). The multiplications were done to model expenditures forgone due to flooding and thus formed the basis of the IMPLAN analysis in each of the 54 BEAbased regional models. By crop, corn comprised the largest proportion of the expenditures

\footnotetext{
${ }^{5}$ Costs in $2018 \$$ included in this analysis were fuel and lube, N, P, and K fertilizer, labor, other chemicals, and seed. Analysis of unpublished survey data of agricultural chemical providers also indicated substantial reductions in farmer chemical purchases in our region of analysis.
} 


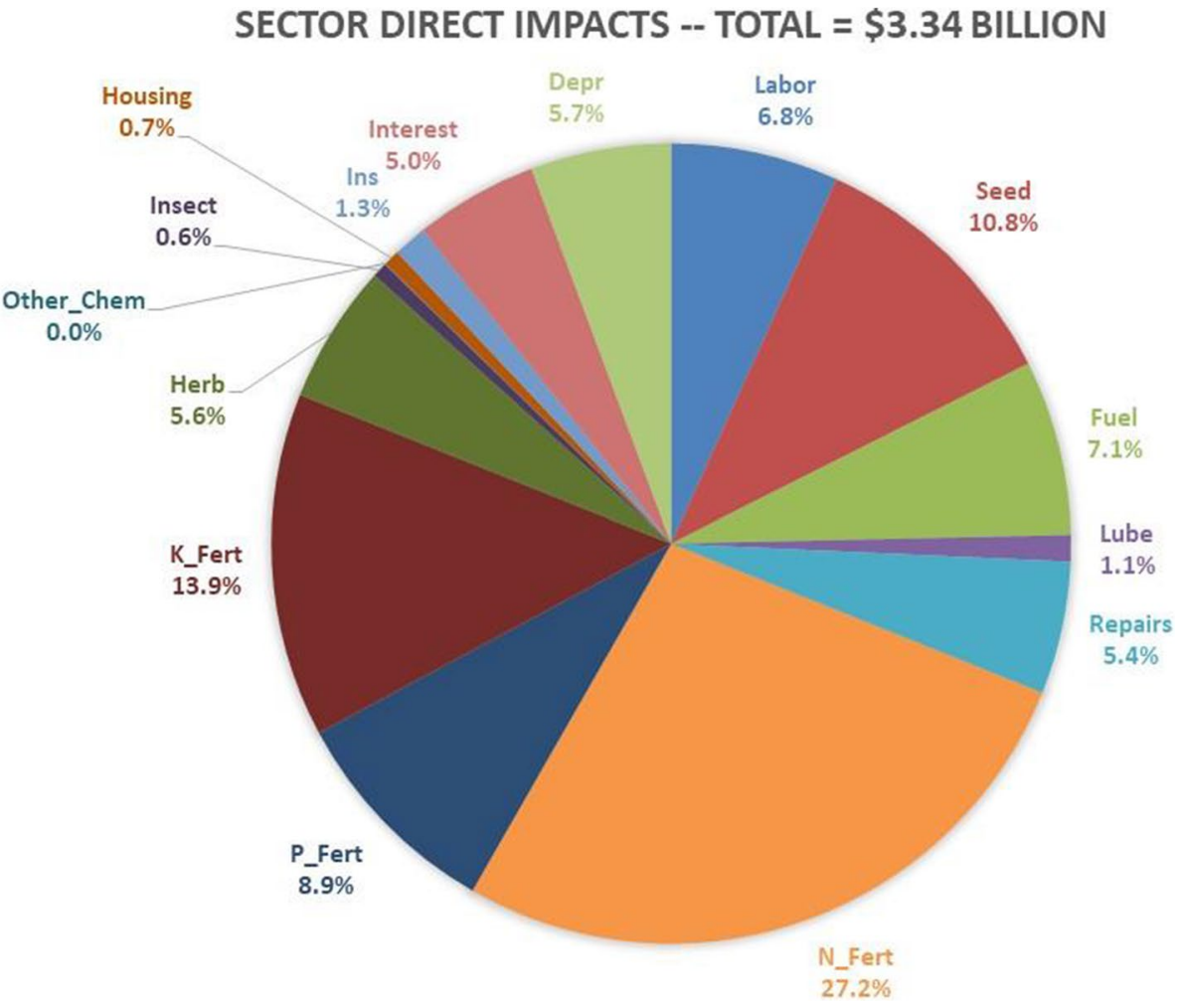

Fig. 3 Input proportions of variable and fixed expenditures foregone due to the increase in 2019 prevented planting acres when compared to the 10-year average

foregone at $82.5 \%$ ( $\$ 2.41$ billion), followed by soybeans at $15.4 \%$ ( $\$ 0.45$ billion), wheat at $1.3 \%$ ( $\$ 0.04$ billion), and upland cotton at $0.8 \%$ ( $\$ 0.02$ billion). The total direct transactions foregone by the producers are estimated at $\$ 2.9$ billion. Across the entire U.S. in 2019 , there were 13.1 million prevented planted acres in excess of the 10 -year average with over $99 \%$ of these acres located in the study region. Acres prevented planted included 8.57, 0.37, 3.25, and 0.83 million acres in corn, upland cotton, soybean, and wheat, respectively. All budgeted applications of inputs were viewed to not occur such as fall/pre-planting fertilizer or other input applications because of lack of information, as well as the differences in management styles of crop producers' and soils affecting productivity across the region. ${ }^{6}$

\footnotetext{
${ }^{6}$ Based on variable costs categories from POLYSYS, purchased inputs (chemical fertilizers, pesticides, herbicides, other chemicals, lube, and fuel) were allocated to appropriate IMPLAN sectors based on a process of margining as explained in Module 6 of McFadden et al. (2016), while labor, seed, and repairs were assigned directly to appropriate IMPLAN sectors. Fixed costs including housing, interest, and insurance were assumed not to be impacted by the flood Regional purchase coefficients in each of the BEA region were then used to determine the amount of spending in the region versus regional imports (leakages).
} 
Table 1 Estimated direct economic impacts by IMPLAN sector as a result of 2019 increased prevented planting acres in the Midwest BEA study region

\begin{tabular}{lll}
\hline $\begin{array}{l}\text { IMPLAN Sec- } \\
\text { tors }\end{array}$ & Sector Description & $\begin{array}{l}\text { Direct Fore- } \\
\text { gone Expendi- } \\
\text { tures }\end{array}$ \\
\hline 19 & & $\$ 851,560,817$ \\
156 & Support activities for agriculture \& forestry & $\$ 148,424,494$ \\
159 & Petroleum refineries & $\$ 20,754,920$ \\
169 & Petroleum lubricating oil \& grease manufacturing & $\$ 505,300,952$ \\
170 & Nitrogenous fertilizer manufacturing & $\$ 164,941,810$ \\
171 & Phosphatic fertilizer manufacturing & $\$ 258,184,953$ \\
172 & Fertilizer mixing & $\$ 120,367,389$ \\
395 & Pesticide \& other agricultural chemical manufacturing & $\$ 267,954,812$ \\
399 & Wholesale trade & $\$ 264,549,871$ \\
402 & Retail - Building material \& garden equipment \& supplies stores & $\$ 49,812,375$ \\
408 & Retail - Gasoline stores & $\$ 1,718,385$ \\
409 & Air transportation & $\$ 50,604,103$ \\
410 & Rail transportation & $\$ 743,416$ \\
411 & Water transportation & $\$ 30,481,875$ \\
413 & Truck transportation & $\$ 1,131,011$ \\
504 & Pipeline transportation & $\$ 179,143,434$ \\
& Automotive repair \& maintenance, except car washes & $\$ 2,915,674,616$ \\
\hline
\end{tabular}

\section{Results and Discussion}

\section{Estimated Direct Expenditures}

As a result of prevented planted acres in the 2019 crop year, $87.3 \%$ of total budgeted costs ( $\$ 2.9$ billion) are foregone by producers. The input costs foregone are concentrated in the fertilizer industry. Slightly more than $55 \%$ of the transactions lost in the community were from nitrogen, potassium, or phosphorous fertilizers (Fig. 3). The BEAs also saw a decline in seed $(13 \%)$ and fuel $(10 \%)$. Where appropriate, farm level expenditures were margined based on IMPLAN national data before modeling at the BEA level to derive total economic impacts for reduced economic activity (for a discussion of margining, see Module 6, McFadden et al. 2016). The set of industry level direct economic impacts are shown in Table 1.

\section{Estimated Total Economic Impacts}

Of the $\$ 2.9$ billion in direct foregone expenditures across all of the 54 BEA regions in our analysis, $61 \%$ occurred directly within each of the specific BEA subregions. An additional $25 \%$ was initially made outside the study regions (i.e., leakage not included in the direct shocks per BEA model). The remaining $14 \%$ was cross subregions direct spending (for example, spending from the Chicago subregion to the Sioux Falls, SD subregion) 


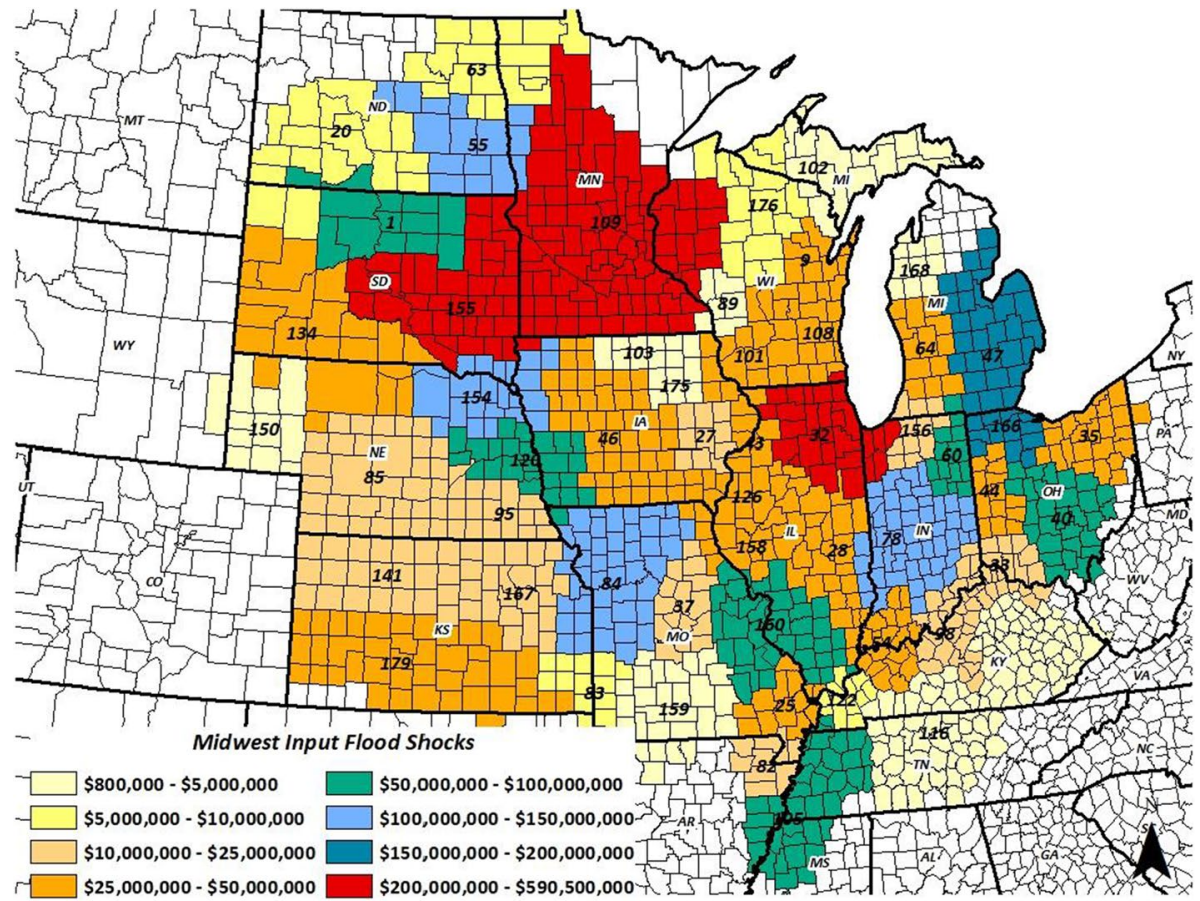

Fig. 4 Proportion of Direct, Indirect, and Induced reduction in economic activity and gross regional product from 2019 Midwest economic impacts from prevented planting acres in the BEA economic areas economies

that is unaccounted for in our subregion impacts.. ${ }^{7}$ The estimated total economic loss in the study area was $\$ 4.5$ billion with a decrease in gross regional product of $\$ 2.8$ billion (Fig. 4). As a comparison, the National Oceanic and Atmospheric Administration (NOAA) published a CPI-adjusted estimated cost of \$6.4 billion for the 2019 Mississippi River, Midwest and Southern flooding event that occurred between March 15 and July 31 (NOAA 2021). ${ }^{8}$

The economic impacts are presented spatially in Fig. 5. BEAs 155 (Sioux Falls, SD), 109 (Minneapolis-St. Paul-St. Cloud, MN-WI), and 32 (Chicago-Naperville-Michigan City, IL-IN-WI) in eastern South Dakota, Minnesota, and northeastern Illinois and northwestern Indiana had the largest impact from the floods and subsequent decrease in purchases resulting from the prevented planting acres. The economic losses from these three BEAs totaled $\$ 1.1$ billion or $35 \%$ of the economic losses that occurred within the study region. Slightly more than $50 \%$ of economic losses occurred in six BEAs - primarily western Missouri (84 or Kansas City-Overland Park-Kansas City, MO-KS), primarily eastern Michigan (47

\footnotetext{
7 An economic model of all of the modeled BEA subregions as one economy was used in making this determination. This process allows the estimation of the degree of cross-subregion direct spending, but not specifically where such spending occurred. Estimating these cross-region impacts would require a multiregion model showing trading relationships between each of our BEA subregions. While IMPLAN does have a multi-region option, it does not extend to simultaneously including 54 trading regions.

8 NOAA study area and methodology different with this analysis.
} 
Fig. 5 Estimated reduction in economic activity from 2019 Midwest economic impacts from prevented planting acres in the BEA economic areas economies

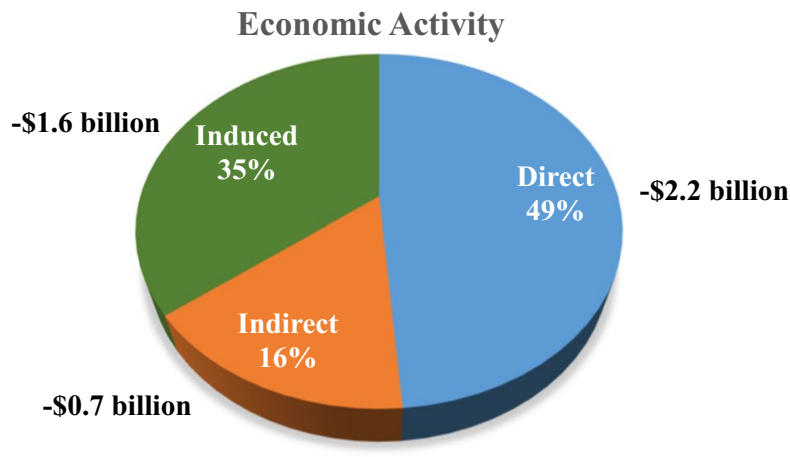

Total $\mathbf{- \$ 4 . 5}$ billion

Gross Regional Product

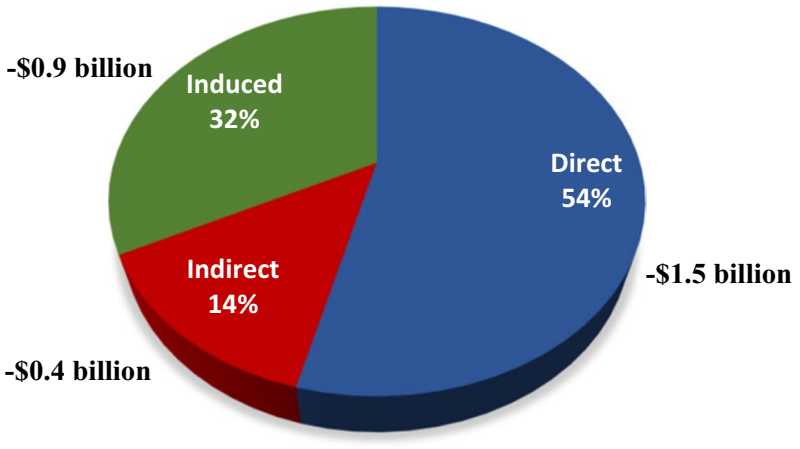

Total -\$2.8 billion

or Detroit-Warren-Flint, MI), and northwestern Ohio (166 or Toledo-Fremont, $\mathrm{OH}$ ), along with the previously identified BEA regions $(32,109$, and 155).

Nearly $85 \%$ of the reduction in economic activity as a result of prevented planting acreage is concentrated in eight industrial sectors (Fig. 6). The largest sector impacted is the services sector with an estimated $\$ 1.01$ billion loss in activity (with more than $50 \%$ occurring as a decrease in Regional Gross Domestic Product). Of this over \$1 billion loss, $\$ 0.86$ billion is in Agricultural Services. Other sectors experiencing relatively large impacts included retail trade ( $\$ 0.46$ billion), agricultural input producers $(\$ 0.41$ billion), and wholesale trade ( $\$ 0.39$ billion). Impacts in all other sectors are less than $\$ 0.3$ billion.

\section{Discussion}

The unprecedent flooding in 2019 occurred during a crop cycle that also included a market distorting trade war with China and several other countries. However, producer decisions regarding crops planted and input strategies were largely made prior to the 2019 flood and with full consideration of the ongoing trade disputes and the associated risks. Market Facilitation Program (MFP) payments occurred in 2018 and 


\section{Estimated Decreases in Economic Activity}

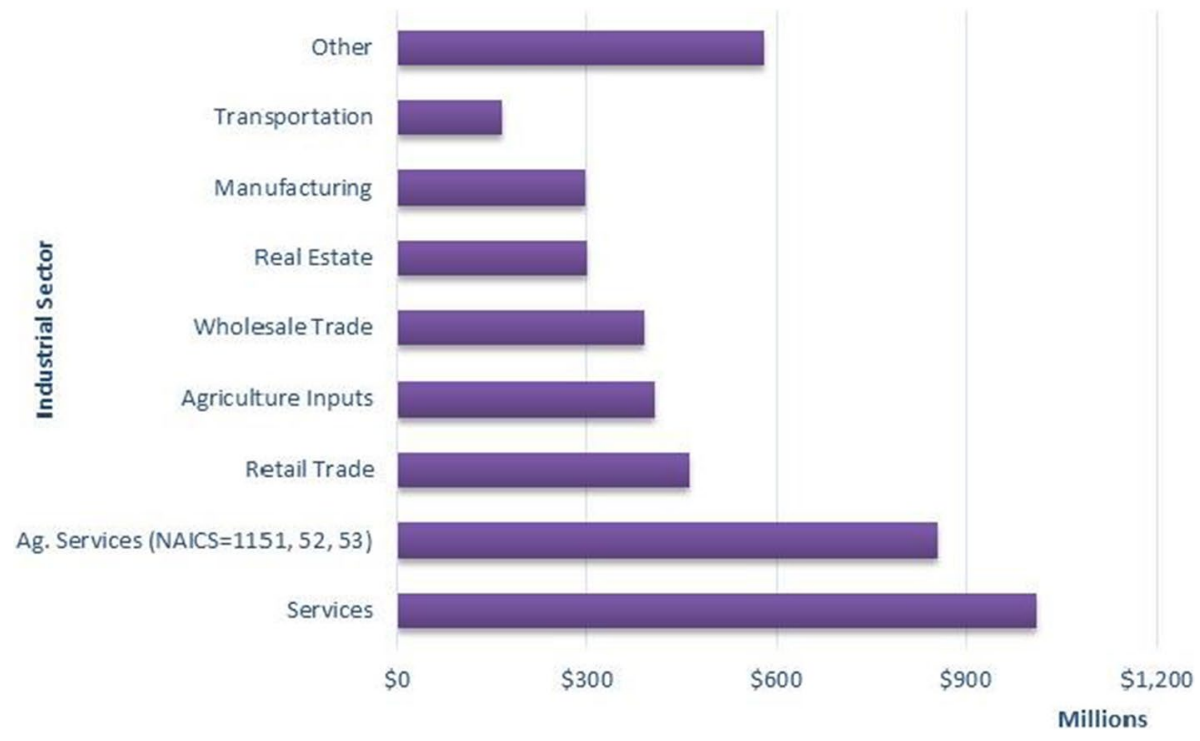

Fig. 6 Estimated declines in economic activity due to an increase in 2019 prevented planting acres when compared to the last ten years

2019 to assist in mitigating the decline in producer income from the trade war. As such, the effectiveness of the Farm Bill (crop insurance and commodity program) and Ad Hoc (WHIP+) programs in mitigating declines in producer income from the 2019 flood are difficult to evaluate. In general, prevented planting crop insurance indemnities, WHIP+, and commodity program (ARC/PLC) payments mitigated a portion of producer level losses in income. This did not preclude decade high Chapter 12 farm bankruptcies in calendar year 2019 for Kansas, Nebraska, Iowa, Minnesota, Wisconsin, Illinois, and Ohio (Newton and Pascoe 2020). However, Chapter 12 farm bankruptcies were down in Tennessee, Kentucky, and Indiana from 2018 to 2019. Data is currently not available to ascertain if the bankruptcies were a result of the 2019 record prevented planting, low prices -- due partially to a trade war, poor management overtime, or other factors. It is also important to note that the long-term effects of the record flooding on producer income may not be known for several years. For example, damage to crop land may result in lower yields in 2020 and 2021 or require producers to incur costly reclamation expenses to make the land suitable for agricultural production again. Further investigation into the long-term consequences of the flood on producer income and the effectiveness of current policies on mitigating short- and long-term income losses is warranted.

Agricultural input suppliers did not receive assistance from government programs to mitigate the adverse effect of the 2019 flood on income. Because these are Secretary of Agriculture declared disaster areas, only agricultural producers can access benefits (primary low-interest loans). Under Small Business Administration declared disasters, agricultural input suppliers that are small businesses (under 500 employees) do qualify for assistance (U.S. Small Business Administration 2020; USDA Farm Service Agency 2020). Thus, the loss to input suppliers was immediate and unrecoverable. While data 
specific to agricultural input supply companies lost sales and the adverse results (i.e. bankruptcies) was not available, estimated income declines can be inferred based on producer budgeted cost of production estimates from USDA-ERS. The USDA-ERS estimated producer expenses for inputs (seed, fertilizer, and chemicals) are gross revenue sources for input suppliers. Thus, analysis of producer expenses aggregated can provide a comparable for gross revenue to the aggregated input supply sector. USDAERS estimated 2019 per acre producer expenses for seed, fertilizer, and chemical at: \$243.35, \$107.98, \$75.87, and \$191.93 per acre for corn, soybean, wheat, and upland cotton. Based on the 2019 prevented planted acres reported by USDA FSA $(8.57,0.37$, 3.25 , and 0.83 million acres of corn, upland cotton, soybean, and wheat). Total decline in gross agricultural retail income would be estimated at $\$ 2.6$ billion $(\$ 2.086, \$ 0.351$, $\$ 0.063$, and $\$ 0.071$ billion for corn, soybean, wheat, and upland cotton). The estimated $\$ 2.6$ billion reduction in gross sales provides some validation of the $\$ 2.9$ billion direct sale losses indicated through our analysis. Based on the March Prospective Planting acreage in the region $(77.36,73.15,12.27$, and 4.34 million acres for corn, soybean, wheat, and upland cotton), this would represent an estimated decline in seed, fertilizer, and chemical sales due to prevented planting acreage of $11.1 \%, 4.4 \%, 6.8 \%$, and $8.5 \%$ for corn, soybean, wheat, and upland cotton input supplies. The financial consequences (i.e. bankruptcies or other financial stress) of this reduction in anticipated income are largely unknown due to insufficient data. One possible policy consideration would be to treat small agricultural input suppliers as producers under the Secretary of Agriculture declared disaster area program.

\section{Conclusions}

Discussion of prevented planting acreage for farmers usually centers on farm income impacts. However, much of the resulting reduction in economic activity is concentrated in input suppliers for producers at both the local and broader regional levels. This analysis focuses on the economic activity impacts of 2019 prevented planting acreage across the Midwest and parts of the South compared to what occurs in a typical year. Our results indicate a loss of an estimated $\$ 4.5$ billion in economic activity and $\$ 2.8$ billion in gross regional product that is especially concentrated in particular Midwest BEA regions. While the analysis ignores some of the other costs that farmer's incur, including impacts on cover crops, crop rotations, forage management, manure storage, and farmers' mental health, the insurance and disaster payments provided a financial safety net for producers.

\section{Appendix}

Acknowledgements We gratefully acknowledge funding by USDA NIFA through Hatch Projects. Any opinions, findings, conclusions, or recommendations expressed in this publication are those of the author(s) and do not necessarily reflect the view of the U.S. Department of Agriculture.

Data Availability The datasets generated during and/or analyzed during the current study are available from the corresponding author on reasonable request. 


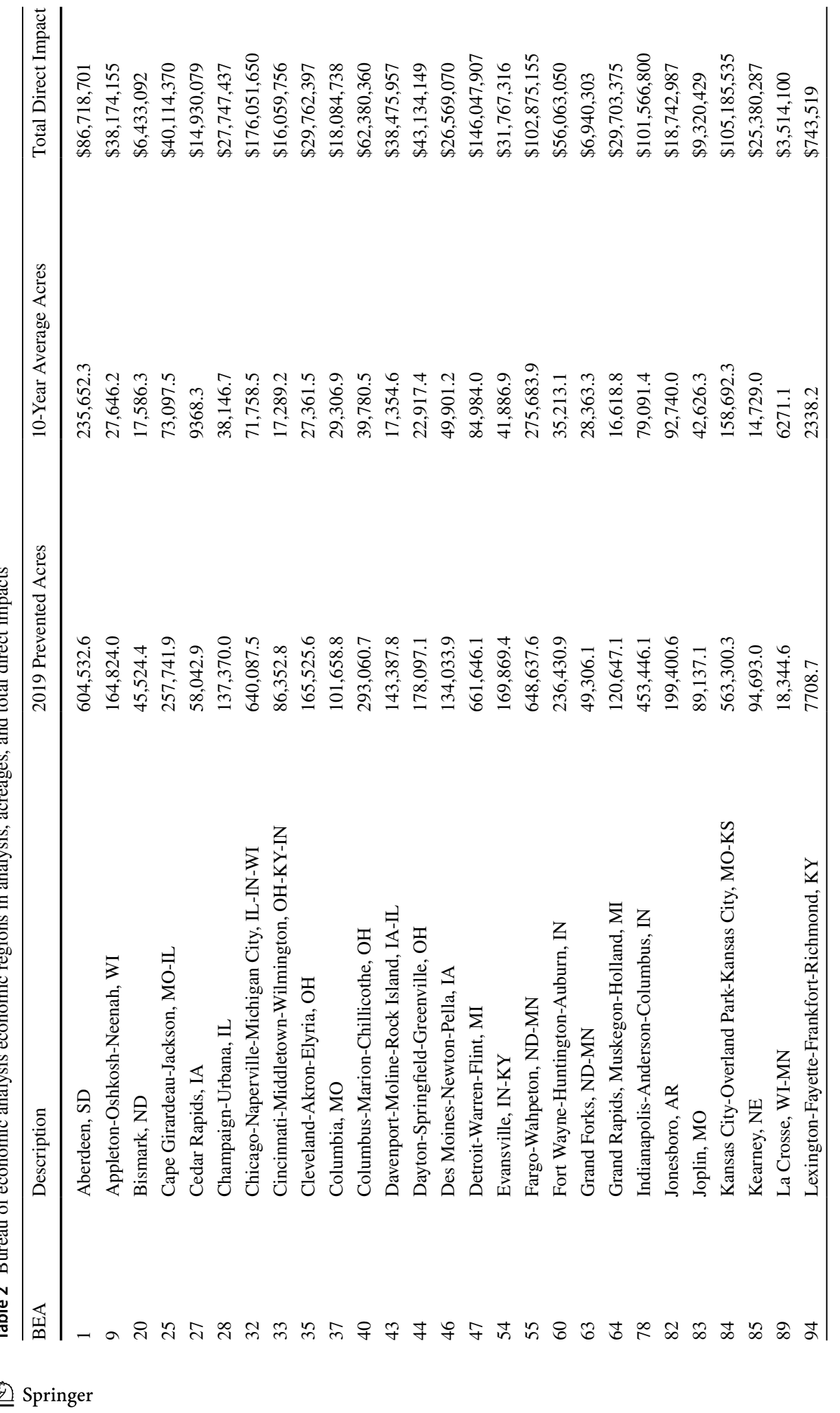




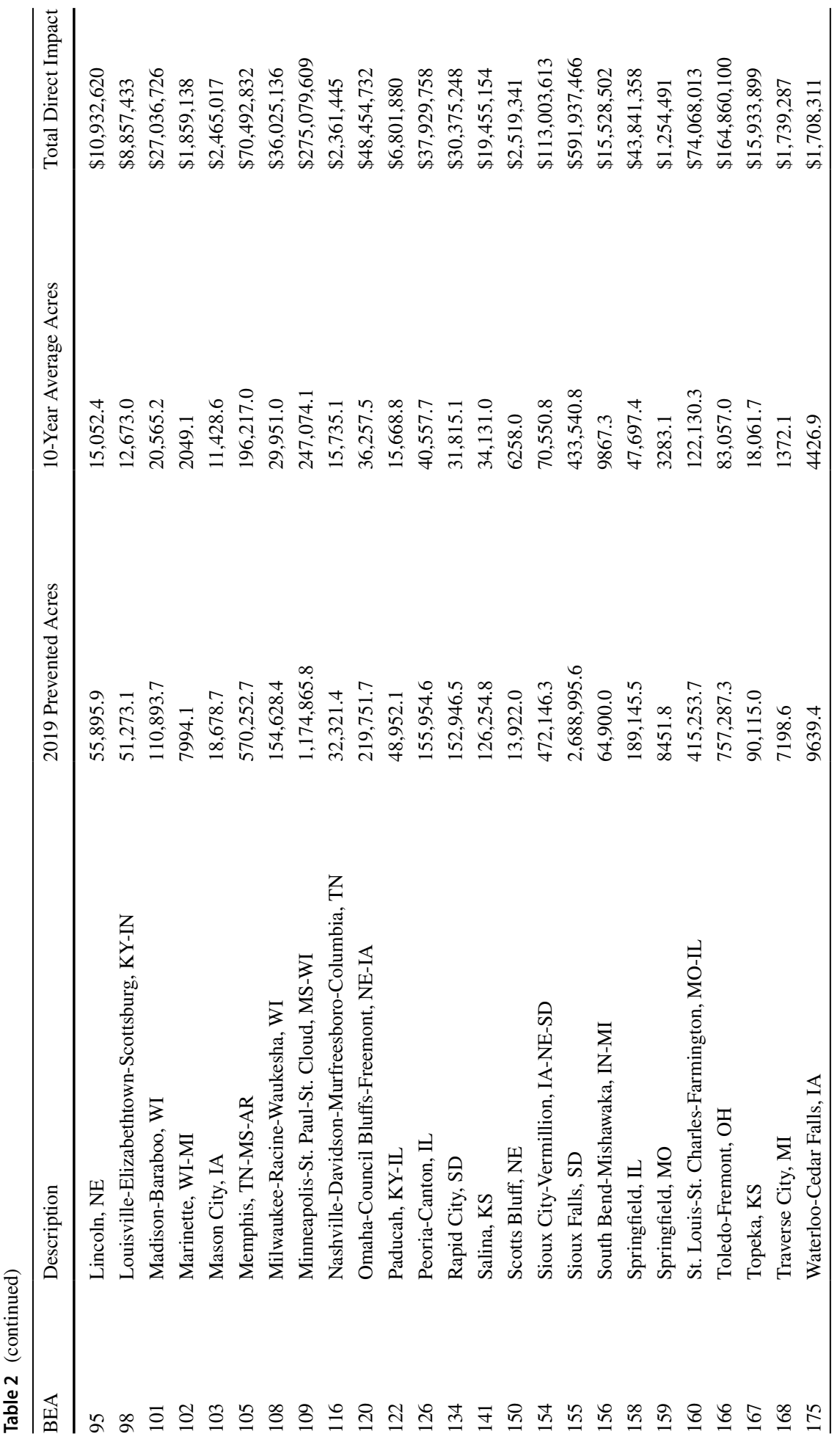




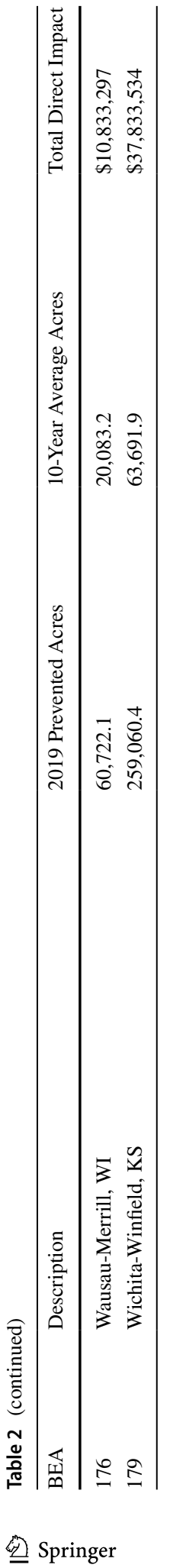


Code Availability Not applicable.

Funding By USDA through Hatch Projects TEN00484 and TEN00574 and University of Tennessee Extension.

\section{Declarations}

Conflicts of Interest/Competing Interests The authors declare they have no financial interest.

Open Access This article is licensed under a Creative Commons Attribution 4.0 International License, which permits use, sharing, adaptation, distribution and reproduction in any medium or format, as long as you give appropriate credit to the original author(s) and the source, provide a link to the Creative Commons licence, and indicate if changes were made. The images or other third party material in this article are included in the article's Creative Commons licence, unless indicated otherwise in a credit line to the material. If material is not included in the article's Creative Commons licence and your intended use is not permitted by statutory regulation or exceeds the permitted use, you will need to obtain permission directly from the copyright holder. To view a copy of this licence, visit http://creativecommons.org/licenses/by/4.0/.

\section{References}

Arndt DS (2002) The Oklahoma drought of 2001-2002. Oklahoma Climatological Survey Climate Event Summary ES 2002-02. https://climate.ok.gov/summaries/event/Drought_of_2001-2002.pdf. Accessed 26 October 2020

Borgomeo E, Vadheim B, Woldeyes FB, Alamirew T, Tamru SS, Charles KJ, Kebede S, Walker O (2018) The distributional and multi-sectoral impacts of rainfall shocks: evidence from computable general equilibrium modelling for the Awash Basin, Ethiopia. Ecol Econ 146:621-632. https://doi.org/10. 1016/j.ecolecon.2017.11.038

Brown S, Gerlt S, Wilcox L (2011) The value of the 2011 crop production loss from the birds point-New Madrid floodway levee breach. Food \& Agricultural Policy Research Institute University of Missouri. https://www.fapri.missouri.edu/wp-content/uploads/2015/02/FAPRI-MU-Report-06-11.pdf. Accessed 26 October 2020

Carrera L, Standardi G, Bosello F, Mysiak J (2015) Assessing direct and indirect economic impacts of a flood event through the integration of spatial and computable general equilibrium modelling. Environ Modelling \& Softw 63:109-122. https://doi.org/10.1016/j.envsoft.2014.09.016

Clouse C (2021) ABP: introduction to analysis by parts (IMPLAN Pro). https://implanhelp.zendesk.com/hc/ en-us/articles/360013968053-ABP-Introduction-to-Analysis-By-Parts. Accessed 27 June 2021

Diersen MA, Taylor G (2003) Examining economic impact and recovery in South Dakota from the 2002 drought. South Dakota State University economics staff paper series. https:/openprairie.sdstate.edu/ econ_staffpaper/ 173/. Accessed 26 October 2020

De La Torre UD, Ray D (2000) Biomass and bioenergy applications of the POLYSYS modeling framework. Biomass Bioenergy 18:291-308. https://doi.org/10.1016/S0961-9534(99)00095-1

De La Torre UD, Ray D, Tiller K (1998) Using the POLYSYS modeling framework to evaluate environmental impacts in agriculture. In: Robertson T, English BC, Alexander RR (eds) Evaluating natural resource use in agriculture. Iowa State University Press, Iowa, pp 151-172 Chapter 6

Hallegatte S (2008) An adaptive regional input-output model and its application to the assessment of the economic cost of Katrina. Risk Anal 28:779-799. https://doi.org/10.1111/j.1539-6924.2008.01046.x

Hellwinckel C (2019) Spatial interpolation of crop budgets documentation of POLYSYS regional budget estimation, version 2. https://arec.tennessee.edu/wp-content/uploads/sites/17/2021/03/POLYSYS_ documentation_3_budgeting_database.Pdf. Accessed 27 June 2021

Hewings G, Mahidhara R (1993) Economic impacts: lost income, ripple effects, and recovery. In: Changnon SA (ed) The great flood of 1993: causes, impacts, and response. Westview Press, Colorado, pp 205-217

Johnson KP, Kort JR (2004) Redefinition of the BEA economic areas. https://apps.bea.gov/scb/pdf/2004/ 11November/1104Econ-areas.Pdf. Accessed 26 October 2020 
Kunkel KE, Angel JR, Changnon SA, Claybrooke R, Hilberg SD, Knapp HV, Larson RS, Palecki M, Scott RW, Winstanley D (2006) The 2005 Illinois drought: chapter 7. https://www.isws.illinois.edu/pubdoc/ IEM/ ISWSIEM2006-03.Pdf. Accessed 26 October 2020

Markel E, English BC, Hellwinckel C, Menard RJ (2018) Potential for pennycress to support a renewable jet fuel industry. Sci Environm 1:121. https://www.hendun.org/viewJournal/RAS211-177/Potential-forPennycress-to-Support-a-Renewable-Jet-Fuel-Industry. Accessed 26 Oct 2020

McFadden DT, Conner D, Deller S et al (2016) The economics of local food systems: a toolkit to guide community discussions, assessments, and choices. https://www.ams. usda.gov/sites/default/files/ media/ toolkit\%20Designed\%20FINAL\%203-22-16.Pdf. Accessed 26 October 2020

Miller R, Blair P (2009) Input-output analyses: foundations and extension. http://static.gest.unipd.it/ birolo/ didattica11/Materiale_2012/_Materiale_2015/Miller_Blait-input-output_analysis.Pdf. Accessed 26 October 2020

Minnesota IMPLAN Group, Inc (2000) IMPLAN professional version 2.0 user's guide, analysis guide and data guide. $2^{\text {nd }}$ Ed., Minnesota, $414 \mathrm{p}$

National Oceanic and Atmospheric Administration (NOAA), National Centers for Environmental Information (NCEI) (2021) U.S. billion-dollar weather and climate disasters. https://www.ncdc.noaa.gov/billi ons/. Accessed 29 June 2021

Nelson RG, Hellwinckel CM, Brandt CC, West TO, De La Torre Ugarte DG, Marland G (2009) Energy use and carbon dioxide emissions from cropland production in the United States, 1990-2004. J Environ Quality 38:418-425. https://doi.org/10.2134/jeq2008.0262

Newton J (2019a) "Prevent plantings set record in 2019 at 20 million acres. https://www.fb.org/market-intel/ prevent-plantings-set-record-in-2019-at-20-million-acres. Accessed 12 October 2019

Newton J (2019b) Estimating prevented planting indemnities and 'top-up' benefits. https://www.fb.org/market-intel/estimating-prevented-planting-indemnities-and-top-up-benefits. Accessed October 2019

Newton J, Pascoe J (2020) The verdict is in: farm bankruptcies up in 2019. https://www.fb.org/market-intel/ the-verdict-is-in-farm-bankruptcies-up-in-2019. Accessed 28 October 2020

Purdue University Center for Commercial Agriculture (2019) Delayed corn \& soybean planting decisions in 2019. https://ag.purdue.edu/commercialag/Pages/Resources/Crop-Insurance/Prevented-and-Delay ed-Plantings/Delayed-Corn\%2D\%2DSoybean-Planting-Decisions-in-2019.aspx. Accessed 12 October 2019

Schnitkey G, Paulson N, Coppess J, Zulauf C (2019) Perspectives on 2019 corn and soybean acres: impact of prevent plant. Farmdoc Daily 9:151. https://ageconsearch.umn.edu/record/298627?ln=en. Accessed 26 Oct 2020

Slinsky SP, Tiller KH (1999) Application of an alternative methodological approach for budget generators for research. J Agric Appl Econ 30:138-149

US Department of Agriculture, Economic Research Service (2000) Farm resource regions. https://www. ers.usda. gov/webdocs/publications/42298/32489_aib-760_002.pdf?v=5855.3. Accessed 27 June 2021

US Department of Agriculture, Farm Service Agency (2019a). Crop Acreage Data. https://www.fsa.usda. gov/news-room/efoia/electronic-reading-room/frequently-requested-information/crop-acreage-data/ index. Accessed 12 October 2019

US Department of Agriculture, Farm Service Agency (2019b). Update of 2019 FSA acreage data and FAQs on USDA acreage. https://www.usda.gov/sites/default/files/documents/NASSandFSAacreage_08222 019.pdf. Accessed 12 October 2019

USDA Farm Service Agency (2020) Disaster assistance programs. https://www.fsa.usda.gov/programsandservices/disaster-assistance-program/index. Accessed 26 Oct 2020

U.S. Small Business Administration (2020) Disaster assistance. https://www.sba.gov/funding-programs/ disasterassistancetance. Accessed 26 Oct 2020

Wang GR, Chen R, Chen J (2017) Direct and indirect economic loss assessment of typhoon disasters based on EC and IO joint model. Nat Hazards 87:1751-1764. https://doi.org/10.1007/s11069-017-2846-y

Zacharia T (1993) Impact on agricultural production: huge financial losses lead to new policies. In: Changnon SA (ed) The great flood of 1993: causes, impacts, and response. Westview Press, Colorado chapter 7

Publisher's Note Springer Nature remains neutral with regard to jurisdictional claims in published maps and institutional affiliations. 